\title{
Efficient Adenoviral-mediated Ornithine Transcarbamylase Expression in Deficient Mouse and Human Hepatocytes
}

\author{
Manal A. Morsy, " Eugene L. Alford, " Andrew Bett," Frank L. Graham," and C. Thomas Caskey * \\ ${ }^{*}$ Institute of Molecular Genetics, ${ }^{\ddagger}$ Department of Otorhinolaryngology, and ${ }^{\boldsymbol{s}}$ Howard Hughes Medical Institute, Baylor College of \\ Medicine, Houston, Texas 77030; and "Departments of Biology and Pathology, McMaster University, Ontario, Canada L8S 4K1
}

\begin{abstract}
$100 \%$ of primary human hepatocytes infected with an adenoviral vector carrying $\beta$-galactosidase expressed the exogenous gene. Expression was also achieved in $>40 \%$ of adult mouse hepatocytes in vivo.

Normal levels of activity were achieved in mouse ornithine transcarbamylase (OTC)-deficient primary hepatocytes using another adenoviral vector carrying human OTC cDNA. Study of OTC-deficient primary human hepatocytes from a single patient confirmed the utility of adenoviral delivery of OTC.

We describe adenoviral-mediated exogenous gene expression in human and mouse hepatocytes in vitro and in mouse liver in vivo. Data suggest that adenoviral vectors may be useful for correcting OTC deficiency. (J. Clin. Invest. 1993.92:15801586.) Key words: ornithine transcarbamylase $\bullet$ human • liver • gene therapy $\bullet \beta$-galactosidase
\end{abstract}

\section{Introduction}

Despite tremendous progress in medicine today, many genetic disorders remain without adequate treatment. A gene augmentation or replacement regimen is therefore an innovative and potentially new solution to this inadequacy.

We have previously proposed that the urea cycle defect ornithine transcarbamylase (OTC) ${ }^{1}$ deficiency is an excellent choice for gene therapy research, since it occurs frequently by new mutation, is cured by hepatic transplantation in some patients, has two mouse models available for experimentation, and the gene is well characterized $(1,2)$. Furthermore, drug therapy for the acute hyperammonemia that occurs during catabolic episodes has shown some benefit, suggesting that longor short-term or partial OTC gene expression may have clinical utility if in vivo delivery and expression could be achieved.

Address correspondence to C. Thomas Caskey, M.D., Institute for Molecular Genetics, Baylor College of Medicine, One Baylor Plaza, Houston, TX 77030.

Received for publication 18 February 1993 and in revised form 24 May 1993.

1. Abbreviations used in this paper: Ad5, adenovirus type 5; HCMV, human cytomegalovirus; OTC, ornithine transcarbamylase; pfu, plaque-forming units; spf, sparse fur; $X$-gal, 5-bromo-4-chloro-3-indolyl- $\beta, \mathrm{D}$-galactosidase; $\beta$-gal, $\beta$-galactosidase.

J. Clin. Invest.

(C) The American Society for Clinical Investigation, Inc. 0021-9738/93/09/1580/07 \$2.00

Volume 92, September 1993, 1580-1586
In recent years, several reports have indicated the utility of defective adenoviral vectors for gene therapy (3-7). Adenoviruses have several features that make them attractive as potential gene therapy agents. They do not require cell proliferation to transfer gene expression (8), can presently accommodate $\leq 8 \mathrm{~kb}$ of foreign DNA, and can easily be produced and purified at titers $>109 \mathrm{ml}(9)$. In addition, although adenovirus serotype 5 in subgenus $C$ is a common cause of upper respiratory tract infection in children $\leq 5 \mathrm{yr}$ of age (10), this virus is not associated with serious illness in immunologically competent individuals or malignancies $(8,11-13)$. Furthermore, for more than two decades, unattenuated adenoviruses have been successfully used as oral vaccines (14). This evidence of the safety of adenovirus reinforces the potential significance of this system as a gene therapy tool. For human gene therapy purposes, evaluation of the vector of choice in human target tissue is essential. Until now, there have been no studies on the use of recombinant adenovirus in primary human hepatocytes despite several successful studies in rodents (3-7).

\section{Methods}

Construction of AdHCMVsplLacZ and AdSRahOTC. The LacZ and the hOTC genes were inserted in the $E 1$ region into different compensatory deletions. The deletions into which the genes were inserted were generated using the same initial plasmid, $\mathrm{pXC1}$ (15), which contains the first 5,788 bp of the adenovirus type 5 (Ad5) genome inserted into the BamHI and Sa1I sites of pBR322. pXCX2, the plasmid into which the hOTC gene was inserted, was generated from $\mathrm{pXC1}$ by deleting Ad5 sequences from the Pvul site at 452 bp to the Bg1II site at $3328 \mathrm{bp}$, and inserting an Xbal cloning site into which SR $\alpha$ hOTC was inserted (16). pHCMVsp1A, the plasmid into which the lacZ gene was inserted, was generated from $\mathrm{pXC} 1$ by deleting Ad5 sequences from the SspI site at $339 \mathrm{bp}$ to the A f III site at $3,533 \mathrm{bp}$. This deletion removes the spII binding site $(3,525-3,530 \mathrm{bp})$ from the protein IX promoter that was reintroduced $1 \mathrm{bp}$ closer to the protein IX TATA box. Various unique cloning sites and the human cytomegalovirus (HCMV) promoter were introduced into the deletion. One other difference between pHCMVsp1A and $\mathrm{pXCl}$ is that $\sim 400 \mathrm{bp}$ of pBR322 sequences were removed between the EcoRI and BamHI sites. The lacZ gene with the SV40 poly A signal was inserted between the Sa1I and XbaI sites of pHCMVsp1A generating pHCMVsp1LacZ. Both pAdSR $\alpha$ hOTC and pHCMVsp1LacZ were rescued into virus by cotransfection with pJM17 (17).

Hepatocyte cultures. Human liver segments preserved in University of Wisconsin solution (18) for liver transplantation were obtained after reduction through the liver tissue procurement and distribution system (19). Under aseptic conditions, $\sim 40 \mathrm{~g}$ of the liver were removed, and hepatocytes were isolated according to Ledley et al. (20). Hepatocytes were infected with recombinant adenoviruses, AdHCMVsplLacZ and AdSRahOTC, as described by Graham and 

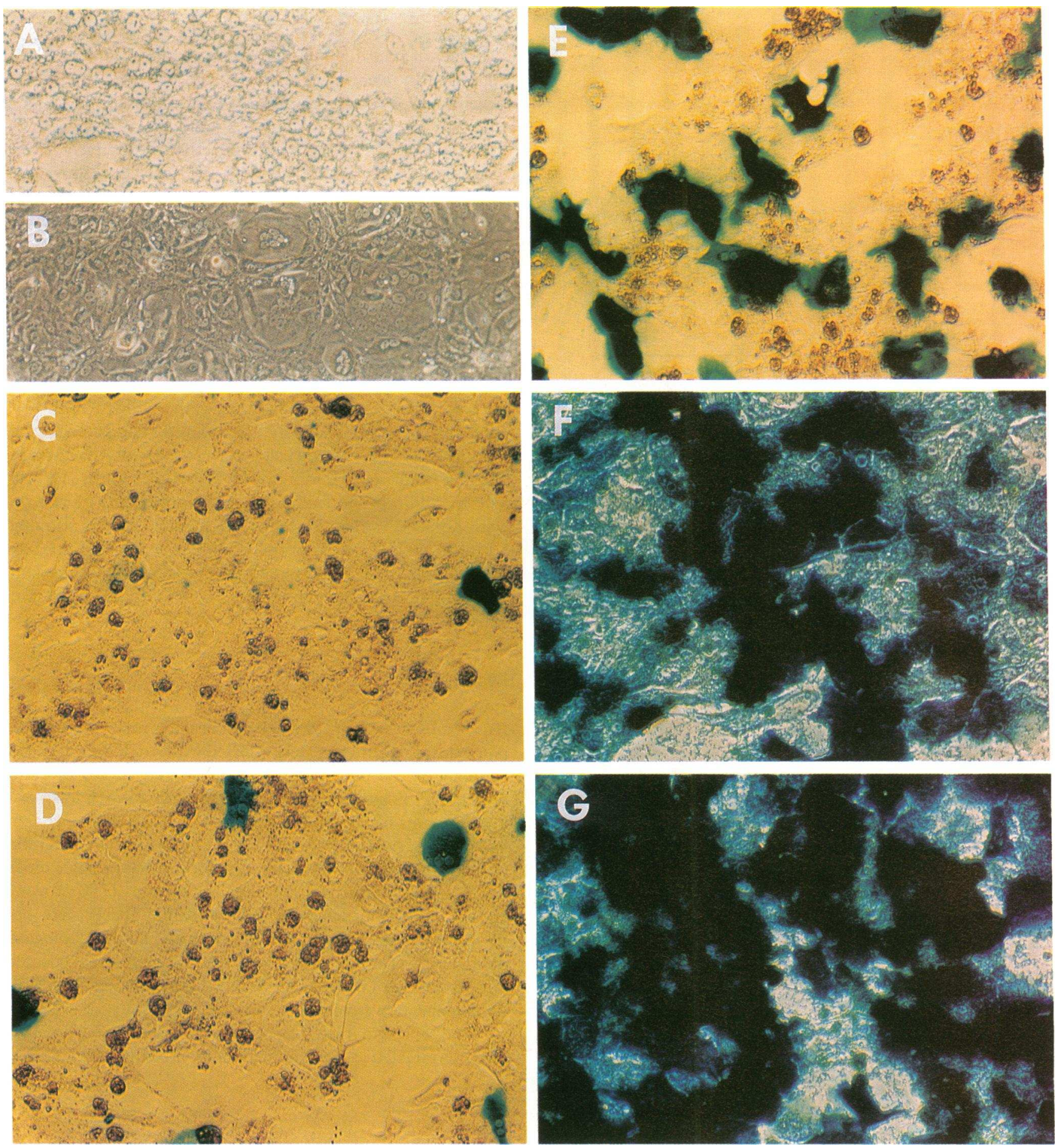

Figure 1. $\beta$-gal expression in vitro. $(C-G)$ Human hepatocyte cultures infected with AdHCMVsp1LacZ at 10, 20, 50, 100, and 200 moi, respectively. $(A)$ Cultures stained immunohistochemically after incubation with $\alpha_{1}$ antitrypsin antibodies. $(B)$ Control hepatocytes infected with AdSR $\alpha$ hOTC at moi of 200.

Prevec (9). Cells were exposed to the viral suspensions $48 \mathrm{~h}$ after plating for $1 \mathrm{~h}$ at room temperature with a range of multiplicities of infection, based on plaque-forming units ( pfu) defined on the 293 cell line (21). Controls were subjected to the same infection conditions, except that virus-free suspension buffer was used (phosphate-buffered saline with $\mathrm{Ca}^{2+}, \mathrm{Mg}^{2+}$, and $10 \%$ glycerol). $1 \mathrm{~h}$ after infection, cells were washed with phosphate buffered saline followed by the addition of culture media. Mouse-derived hepatocytes cultures were prepared essentially as described by Grompe et al. (1).

Histochemical staining. Cells were fixed and evaluated for the expression of Escherichia coli $\beta$ gal enzyme activity after staining with 5-bromo-4-chloro-3-indolyl- $\beta$, D-galactosidase (X-gal stain), and $\alpha_{1}$ antitrypsin. Cultures were fixed in $0.5 \%$ glutaraldehyde (Sigma Immunochemicals, St. Louis, MO) and stained as described (22). For immunohistochemical staining, cultures were fixed in $0.5 \%$ glutaraldehyde and incubated with a 1:1,200 dilution of rabbit anti- $\alpha_{1}$ antitrypsin antibody (Atlantic Antibodies, Scarborough, ME). Immunoperoxidase staining was performed using the Vectastain $A B C$ method (Vector Laboratories, Inc., Burlingame, CA), and hematoxylin was used as a counter stain.

OTC assay. Cells were harvested by scraping into $0.25 \mathrm{M} \mathrm{Tris} / \mathrm{HCl}$, pH 7.2, and total protein was extracted by repeated freeze thaw cycles. 


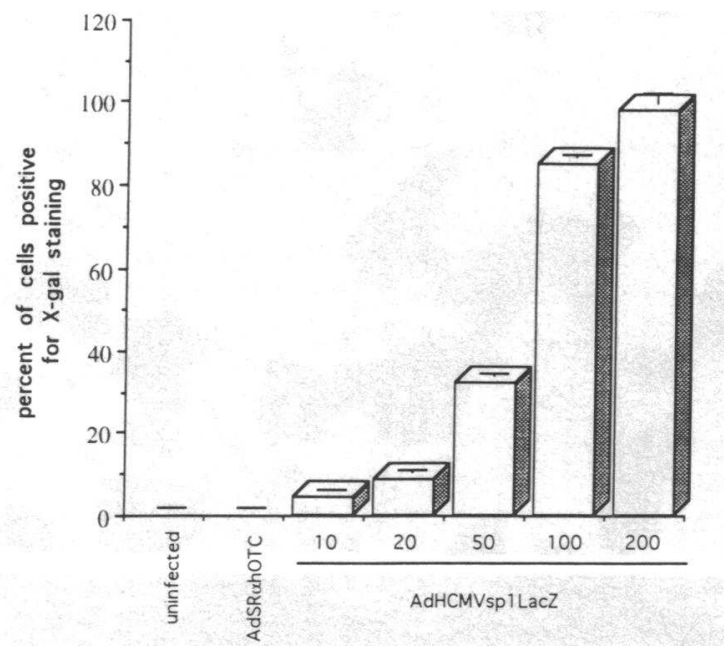

Figure 2. Primary human hepatocytes cultures $(n=3)$ were evaluated for $\beta$ gal activity $72 \mathrm{~h}$ after AdHCMVsp $1 \mathrm{LacZ}$ infection by scoring the percentage of blue stained cells.

OTC enzyme activity was measured according to Jones et al. (2) using $50 \mu \mathrm{g}$ of protein for the assay in a final volume of $100 \mu \mathrm{l}$ for $1 \mathrm{~h}$.

In vivo viral delivery. 2-mo-old C3H/HENCRMTV mice were anesthetized and their abdomens were opened, exposing the portal vein or the spleen. Intraportal or intrasplenic injections with $1 \times 10^{10}$ and 2 $\times 10^{10}$ pfu of AdHCMVsp $1 \mathrm{LacZ}$ in 100 and $200 \mu$ l of viral suspension buffer ( $\mathrm{PBS}^{++}$plus $10 \%$ glycerol), respectively, or with virus-free suspension buffer were performed using a 30 -gauge needle.

Frozen sections. Liver tissue was snap frozen by plunging into liquid nitrogen-cooled isopentane. $8-\mu \mathrm{m}$ sections were fixed in $2.5 \%$ glutaraldehyde and stained with X-gal as described (22).

\section{Results}

Adenoviral-mediated gene expression in human hepatocytes. Cultured human hepatocytes infected with recombinant adenovirus efficiently expressed exogenous genes. We constructed and used an Ad vector (AdHCMVsp1 LacZ) carrying an early region 1 (E1) substitution of an expression cassette consisting of HCMV immediate early gene promoter driving bacterial $\beta$ gal expression to infect human hepatocytes. Cultures were infected with AdHCMVsp1LacZ at different moi (Fig. 1, C$G) .100 \%$ of the cells expressed $\beta$ gal when infected at an moi of 200 or $400 \mathrm{pfu} /$ cell at $72 \mathrm{~h}$ and $\leq 2 \mathrm{wk}$ after infection (Fig. 2). Cells infected at moi's of $10,20,50$, and 100 yielded expression ranging from 2 to $84 \%$ (Fig. 2).

With respect to cell morphology (Fig. 1, B, C-G) and endogenous OTC activity (Fig. 3 ), infected cultures were comparable to controls. The culture conditions used select against nonhepatocyte liver cells (23), and $>95 \%$ of the surviving cells were hepatocytes, as shown by morphology and immunohistochemical staining with antibody to the hepatocyte-specific enzyme marker, $\alpha_{1}$ antitrypsin (Fig. $1 A$ ).

Adenoviral-mediated expression in vivo. Adult mice were used to evaluate the efficiency of adenoviral gene transduction in vivo. Estimation of the proportion of cells expressing $\beta$-galactosidase ( $\beta$-gal) from frozen sections was difficult because of the patchy distribution of expressing cells (Fig. $4 \mathrm{~B}$ ). Some areas were densely stained, while others showed sparse staining with no apparent overall pattern. Therefore, for a more reliable estimate of transduction, livers were cultured, and $24 \mathrm{~h}$ after plating, they were fixed, stained, and evaluated (Fig. $4 \mathrm{~A}$ ). Splenic $(n=8)$ or intraportal $(n=8)$ infusions of $1 \times 10^{10}$ and $2 \times 10^{10}$ pfu resulted in $21.6 \pm 7.5$ and $42.4 \pm 6.7 \%$ of cells expressing $\beta$ gal activity $72 \mathrm{~h}$ after infection, respectively. Livers perfused and stained in situ $72 \mathrm{~h}$ after infection showed an overall positive $\beta$ gal staining with no confinements to any specific area or lobe of the liver (Fig. 5). No morphologic differences (gross or microscopic) were found between control (uninfected, AdSR $\alpha$ hOTC, or viral suspension buffer-mock infected) and AdHCMVsp1LacZ-infected mice, and no background staining was found in control livers (Fig. $1 B$ and Fig. 5).

OTC correction in vitro. Hepatocytes derived from sparse fur (spf) mice with $>80 \%$ reduction in endogenous OTC activity were infected $48 \mathrm{~h}$ after plating with AdSRahOTC. 1 wk after infection, OTC activity was assayed. The percentage of OTC activity detected in hepatocytes infected with AdSR $\alpha$ hOTC ranging from 1 to 200 moi ranged between 26 and $151 \%$ relative to wild type-derived hepatocytes uninfected or infected with AdHCMVsp1 LacZ (Fig. 6). AdSR $\alpha$ hOTC was also used to infect OTC-deficient primary human hepatocytes isolated from a severely affected patient undergoing liver transplant. Preliminary data show an increase in OTC activity $4 \mathrm{~d}$ after infection (Fig. 7).

\section{Discussion}

Our results show that essentially all of the primary human hepatocytes in culture that were infected with AdHCMVsp1 LacZ at moi's of 200 or 400 expressed $\beta$ gal activity. Ad mutants defective in postinfection functions, and to a much lesser extent, mutants deleted in E1, can show multiplicity-dependent leakiness in certain cells, particularly at very high pfu /cell ratio $(24,25)$. Exposure of human hepatocytes to the high moi's used in these studies did not alter endogenous OTC enzyme activity levels. Furthermore, no cytopathic effects were observed for as long as $2 \mathrm{wk}$ after infection, and no morphological differences were observed between recombinant virus-infected and uninfected cultures, suggesting that significant levels of virus replication were not occurring.

In vivo, single injections of AdHCMVsp1LacZ $\left(2 \times 10^{10}\right.$ $\mathrm{pfu} / \mathrm{ml}$ ) targeted to the liver in adult mice resulted in $>40 \%$ of

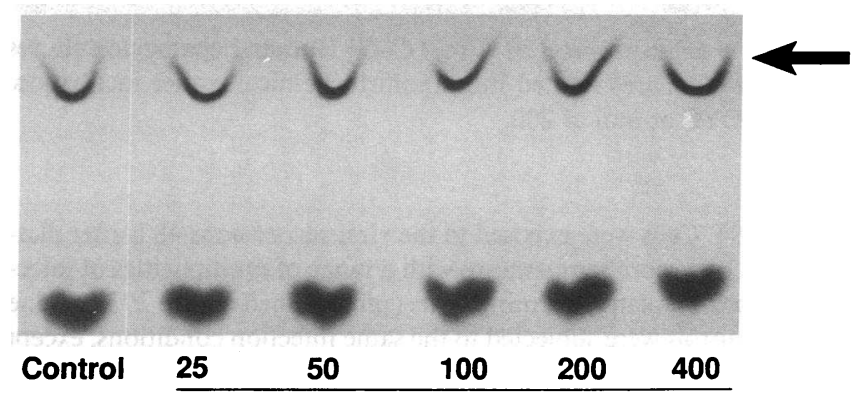

Figure 3. This is an auto radiograph of a TLC plate used to separate the product citrulline (arrow) from the substrate ornithine of the OTC enzyme reaction. The first lane represents uninfected control and the following lanes represent cultures infected with AdHCMVsp 1 LacZ at different moi's. 

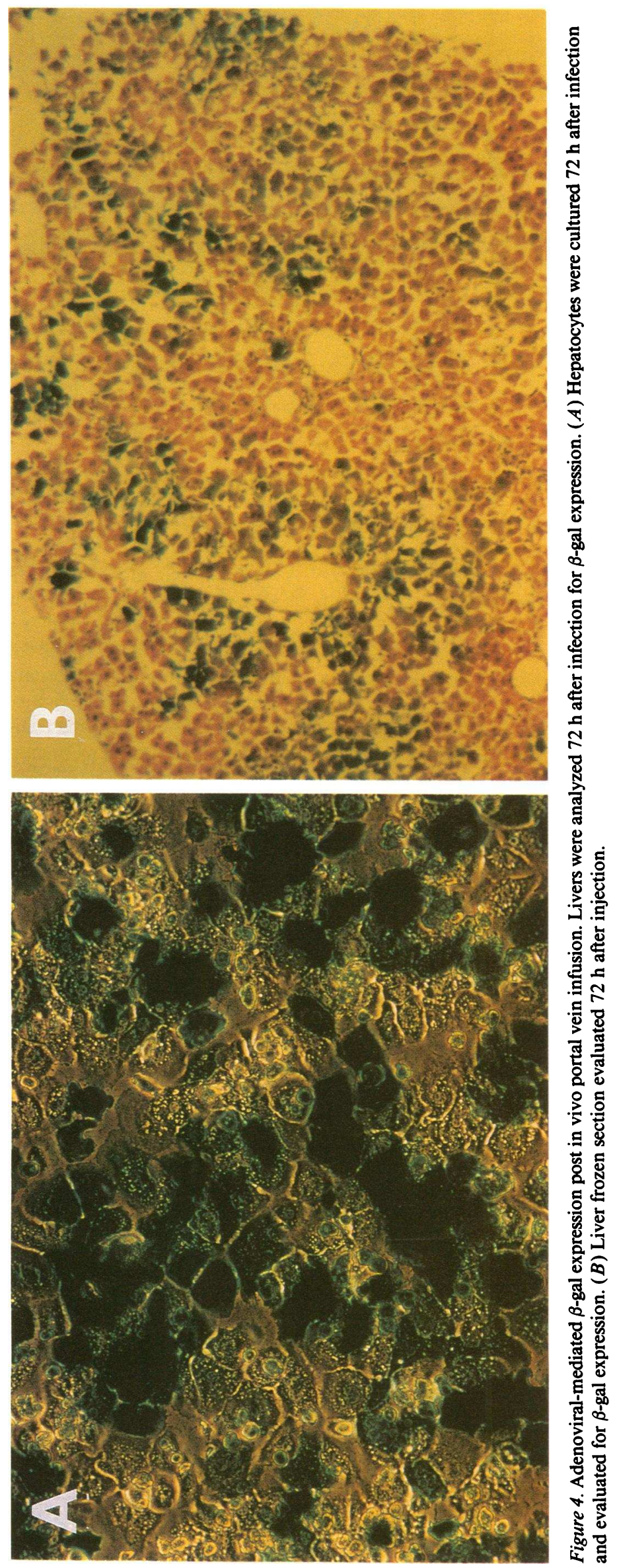


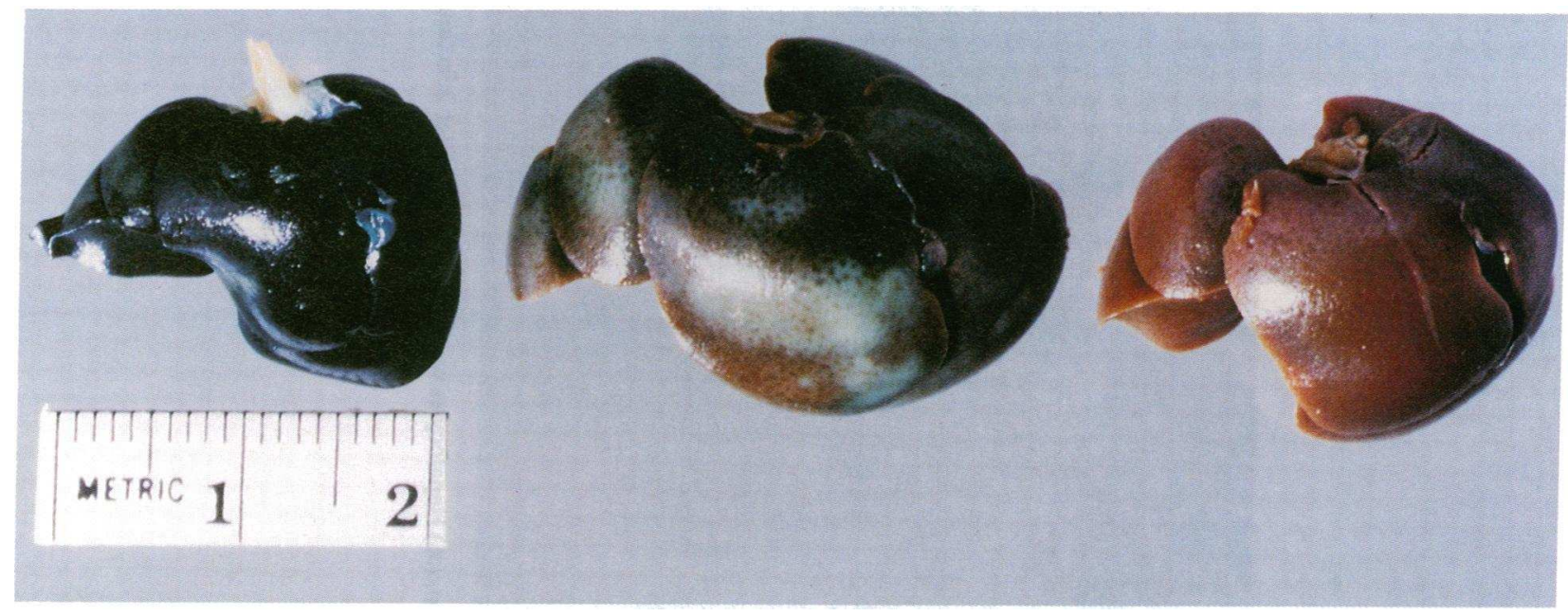

Figure 5. Whole liver was perfused in situ with PBS followed by $2.5 \%$ gluteraldehyde, PBS, and stain. After dissection, livers were incubated for an additional $2 \mathrm{~h}$ in X-gal stain. (Left to right) In vivo portal transfer of $2 \times 10^{10}, 1 \times 10^{10} \mathrm{pfu}$ of AdHCMVsp1LacZ, and $2 \times 10^{10} \mathrm{pfu}$ AdSR $\alpha$ hOTC followed $72 \mathrm{~h}$ after infection, by in situ fixing and $\mathrm{X}$-gal staining of the liver.

cells expressing $\beta$ gal in the liver. The percentage of cells expressing the inserted gene at $72 \mathrm{~h}$ after treatment exceeded levels recently reported by Jaffe et al. ( $62 \%$ in vitro and $<2 \%$ in vivo) (5). This difference may relate to several factors, including the difference in vectors used, promoters, and the amount of recombinant virus injected in relation to the size of the animal $(25-30 \mathrm{~g} /$ mouse vs $250-300 \mathrm{~g} / \mathrm{rat})$. We anticipate that with our vectors, even higher levels of activity may be obtained with minor technical modifications, such as increasing the moi, the time, or repeated inoculation.

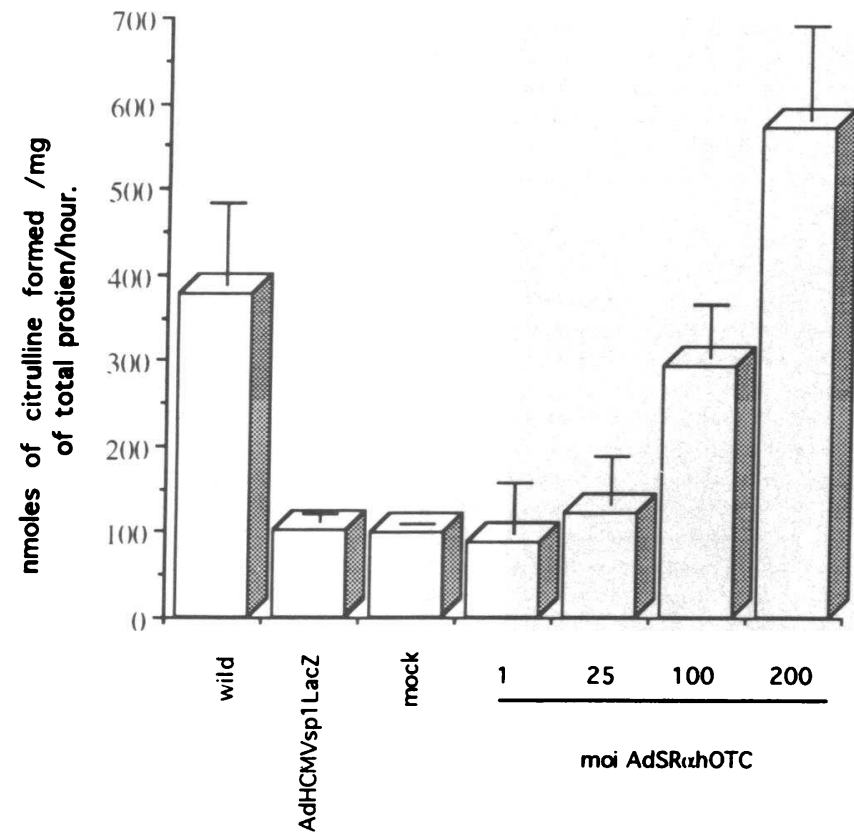

Figure 6. Livers of 2-mo-old spf (OTC-deficient) and C3H/ HENCRMTV mice (wild) (Jackson Laboratories, Bar Harbor, ME) were used for the hepatocyte cultures. OTC-deficient hepatocytes were infected $48 \mathrm{~h}$ after plating at different moi's with AdSR $\alpha$ hOTC, AdHCMVsp 1 LacZ, or suspension media (mock) and evaluated for OTC enzyme activity 1 wk after infection $(n=3)$. Vertical error bars show standard deviations from the mean.
Sparse fur mouse-derived primary hepatocytes, in which OTC activity is $\sim 20 \%$ that of wild type, were fully corrected after infection with recombinant adenovirus carrying the human OTC cDNA under the control of the SR $\alpha$ promoter (26), and the levels of activity equaled or exceeded those of wild type controls. We report the first successful attempt for OTC gene augmentation in human hepatocytes derived from an OTC-deficient patient resulting in an increase in enzyme activity. The wild type levels of OTC expression achieved in this report are the first demonstration of complete correction for the deficiency in vitro. This is significant in terms of OTC gene therapy and in vivo targeting of the liver. We therefore predict, based

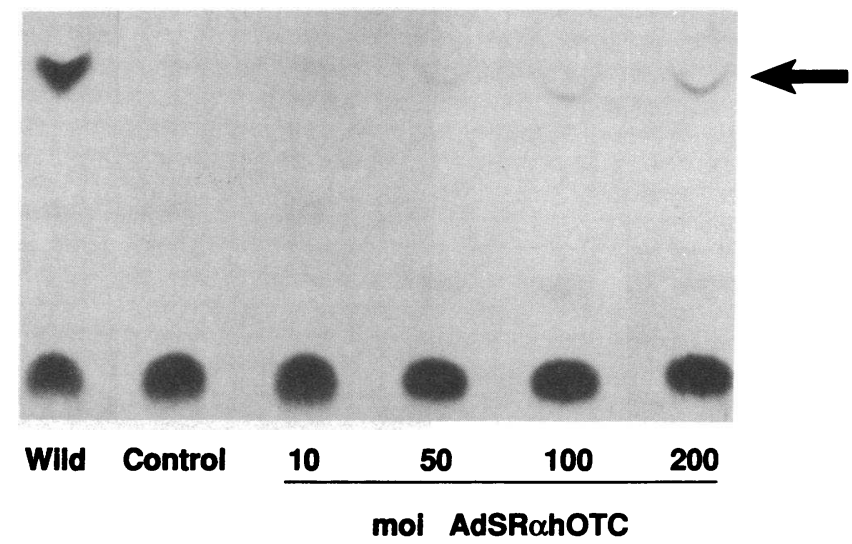

Figure 7. This is an auto radiograph of a TLC plate used to separate the product citrulline (arrow) from the substrate ornithine of the OTC enzyme reaction assay. Human hepatocytes were isolated from both the donor's liver (wild) and from the recipient's liver (control and AdSRahOTC-infected at different mois). The recipient was a severely affected OTC-deficient male with an exon 3 TaqI site mutation. Hepatocytes were assayed $6 \mathrm{~d}$ after plating $(4 \mathrm{~d}$ after Ad vector infection). The first lane (wild) represents wild type enzyme activity found in the hepatocyte cultures from the normal donor liver specimen. The second lane (control) represents the enzyme activity found in the patient's OTC-deficient liver specimen cultures uninfected with AdSR $\alpha$ hOTC, and the following lanes represent OTC-deficient cultures infected with AdSR $\alpha$ hOTC at different moi's. 
on these data and in view of the $\beta$ gal in vitro and in vivo experiments, that corrective levels of OTC enzyme activity can easily be achieved in spf mice and ultimately in human OTC-deficient livers. These experiments are ongoing and should be valuable in determining the adenoviral moi needed to obtain the phenotypic corrective levels of enzyme activity. Since human females heterozygous for the OTC mutation who have $~ 50 \%$ OTC activity are asymptomatic, it should not be necessary to achieve wild type levels of OTC activity for phenotypic correction $(27,28)$. Furthermore, while this paper has focused on hepatic expression; ectopic expression of OTC in the small bowels of transgenic sparse fur mice corrected the urea cycle metabolic defect (2). These features offer many logical approaches to gene therapy "correction" of OTC deficiency. Strong expression of OTC in deficient patients during a hyperammonemic crisis could be of great benefit, even if the expression is transient. Currently available adenoviral vectors may not support permanent gene expression, because they are not incorporated into the host cell genome. Therefore, the strength of a promoter in such a system may be more relevant than the longevity of the expression. However, for permanent gene therapy, liver-specific or long-term promoters should be of potential benefit.

The safety of adenovirus vectors is an issue that requires further study. Although the adenovirus serotypes 4 and 7 have been used for decades as oral vaccines without significant complications, there are still potential hazards (27-30). This issue is particularly critical in terms of assessing the safety of the currently used replication-defective adenoviruses, since replication-defective adenoviruses lacking after infection can be partially complemented not only by wild type adenovirus, but also by heterologous immediate early proteins of other viruses including HCMV and EBV (31-33). Although the liver is a rare target for clinical adenoviral infection, it can be a target for $\operatorname{HCMV}(34,35)$. Viral vectors deleted in all E1 functions both after infection and E1B, are less likely to manifest leakiness at high mois or be complemented by early functions of heterologous viruses. Nevertheless additional studies are required to evaluate the usefulness of the currently available defective adenovirus vectors and to determine whether additional alterations may be desirable. It is noteworthy in this context that a vast array of Ad mutants, temperature-sensitive in viral functions, is available to generate vectors which are impaired if necessary.

This study suggests that adenoviral vectors may provide a powerful tool for transduction of high level gene expression in the liver and moves us one more step toward clinical gene therapy trials. In the case of OTC deficiency, short- and/or long-term expression would have utility.

\section{Acknowledgments}

We are grateful to P. Wood and L. Swisher for providing us with the OTC-deficient liver and an unused portion of the donor liver at Texas Children's Hospital. We thank B. J. F. Rossiter for her valuable assistance in preparing the manuscript; M. Abdellatif, P. Clemens, and J. Pearlman for their critical review; and J. Rudy and P. Jones for their technical assistance.

Funding was provided by the National Institutes of Health. C. T. Caskey is also a Howard Hughes Medical Institute Investigator and F. L. Graham is a Terry Fox Research Scientist of the National Cancer Institute of Canada.

\section{References}

1. Grompe, M., S. N. Jones, H. Loulseged, and C. T. Caskey. 1992. Retroviral-mediated gene transfer of human ornithine transcarbamylase into primary hepatocytes of $s p f$ and $s p f$-ash mice. Hum. Gene Ther. 3:35-44.

2. Jones, S. N., M. Grompe, M. I. Munir, G. Veres, W. J. Craigen, and C. T. Caskey. 1990. Ectopic correction of ornithine transcarbamylase deficiency in sparse fur mice. J. Biol. Chem. 265:14684-14690.

3. Stratford-Perricaudet, L. D., M. Levrero, J. F. Chasse, M. Perricaudet, and P. Briand. 1990. Evaluation of the transfer and expression in mice of an enzymeencoding gene using a human adenovirus vector. Hum. Gene Ther. 1:241-256.

4. Rosenfeld, M. A., W. Siegfried, K. Yoshimura, K. Yoneyama, M. Fukayama, L. E. Stier, P. K. Pääkkö, P. Gilardi, L. D. Stratford-Perricaudet, M. Perricaudet, et al. 1991. Adenovirus-mediated transfer of a recombinant alpha-1antitrypsin gene to the lung epithelium in vivo. Science (Wash. DC). 252:431434.

5. Jaffe, H. A., C. Danel, G. Longenecker, M. Metzger, Y. Setoguchi, M. A. Rosenfeld, T. W. Grant, S. S. Thorgeirsson, L. D. Stratford-Perricaudet, M. Perricaudet, et al. 1992. Adenovirus-ediated in vivo gene transfer and expression in normal rat liver. Nature Genet. 1:372-378.

6. Stratford-Perricaudet, L. D., I. Makeh, M. Perricaudet, and P. Briand. 1992. Widespread long-term gene transfer to mouse skeletal muscles and heart. $J$. Clin. Invest. 90:626-630.

7. Rosenfeld, M. A., K. Yoshimura, B. C. Trapnell, K. Yoneyama, E. R. Rosenthal, W. Dalemans, M. Fukayama, J. Bargon, L. E. Stier, L. Stratford-Perricaudet, et al. 1992. In vivo transfer of the human cystic fibrosis transmembrane conductance regulator gene to the airway epithelium. Cell. 68:143-155.

8. Horwitz, M. S. 1990. Adenoviridae and their replication. In Virology. 2nd ed. B. N. Fields and D. M. Knipe, editors. Raven Press, Ltd., New York. pp. 1679-1721.

9. Graham, F. L., and L. Prevec. 1991. Gene transfer and expression protocols. In Methods in Molecular Biology. 3rd ed. E. J. Murray, editor. The Humana Press Inc., Totowa NJ. pp. 109-128.

10. Fox, J. P., C. D. Brandt, F. E. Wassermann, C. E. Hall, I. Spigland, A. Kogon, and L. R. Elveback. 1969. The virus watch program: a continuing surveillance of viral infection in metropolitan New York families. VI. Observations of adenovirus infections: virus excretion patterns, antibody response, efficiency of surveillance, patterns of infections, and relation to illness. Am. J. of Epidem. 89:25-50.

11. Graham, F. L. 1984. Transformation by and oncogenicity of human adenovirus. In The Adenovirus. H. E. Ginsberg, editor. Plenum Publishing Corp., New York. pp. 339-398.

12. Huebner, R. J. 1967. Adenovirus-directed tumor and T antigens. In Perspectives in Virology. V. M. Pollard, editor. Academic Press, New York. pp. 147-166.

13. Girardi, A. J., M. R. Hilleman, and R. E. Zwickey. 1964. Tests in hamsters for oncogenic quality of ordinary viruses including adenovirus type 7. Proc. Soc. Exp. Biol. Med. 115:1141-1150.

14. Rubin, B. A., and L. B. Rorke. 1988. Adenovirus vaccines. In Vaccines. S. A. Plotkin and E. A. Mortimer, Jr., editors. W. B. Saunders Co., Philadelphia, PA 492-512.

15. McKinnon, R. D., S. Bacchetti, and F. L. Graham. 1982. Tn5 mutagenesis of the transforming genes of human adenovirus type 5. Gene. 19:33-42.

16. Spessot, R., K. Inchley, T. M. Hupel, and S. Bacchetti. 1989. Cloning of the herpes simplex virus ICP4 gene in an adenovirus vector: effects on adenovirus gene expression and replication. Virology. 168:378-387.

17. McGrory, W. J., D. S. Bautista, and F. L. Graham. 1988. A simple technique for the rescue of early region I mutations into infectious human adenovirus type 5. Virology. 163:614-617.

18. Southard, J. H., T. M. val-Gulik, M. S. Ametani, P. K. Vreugdenhil, S. L. Lindell, B. L. Pienaar, and F. O. Belzer. 1990. Important components of the UW solution. Transplantation (Baltimore). 49:251-257.

19. Kalser, S. C., and J. H. Hoofnagle. 1990. Human liver tissue for research. Gastroenterology. 98:1086-1087.

20. Ledley, F. D., S. L. Woo, G. D. Ferry, H. H. Whisennand, M. L. Brandt, G. J. Darlington, G. J. Demmler, M. J. Finegold, W. J. Pokorny, and H. Rosenblatt. 1991. Clinical protocol: hepatocellular transplantation in acute hepatic failure and targeting genetic markers to hepatic cells. Hum. Gene Ther. 2:331358.

21. Graham, F. L., J. Smiley, W. C. Russell, and R. Nairn. 1977. Characteristics of a human cell line transformed by DNA from human adenovirus 5 . J. Gen. Virol. 36:59-72.

22. MacGregor, G. R., A. E. Mogg, J. F. Burke, and C. T. Caskey. 1987. Histochemical staining of clonal mammalian cell lines expressing $E$. coli $\beta$-galactosidase indicate heterogeneous expression of the bacterial gene. Somatic Cell Mol. Genet. 13:253-265.

23. Enat, R., D. M. Jefferson, N. Ruiz-Opazo, Z. Gatmaitan, L. A. Leinwand, and L. M. Reid. 1984. Hepatocyte proliferation in vitro: its dependence on the 
use of serum-free hormonally defined medium and substrata of extracellular matrix. Proc. Natl. Acad. Sci. USA. 81:1411-1415.

24. Shenk, T., N. Jones, W. Colby, and D. Fowlkes. 1979. Functional analysis of adenovirus type 5 host range deletion mutants defective for transformation of rat embryo cells. Cold Spring Harbor Symp. Quant. Biol. 44:367-375.

25. Gaynor, R. B., and A. J. Berk. 1983. Cis-acting induction of adenovirus transcription. Cell. 33:683-693.

26. Takebe, Y., M. Seiki, J. Fujisawa, P. Hoy, K. Yokota, K, Arai, M. Yoshida, and N. Arai. 1988. SR alpha promoter: an efficient and versatile mammalian cDNA expression system composed of the simian virus 40 early promote and the R-U5 segment of human T-cell leukemia virus type 1 long terminal repeat. Mol. Cell. Biol. 8:466-472.

27. Quershi, I. A., J. Letarte, and R. Ouellet. 1979. Ornithine transcarbamylase deficiency in mutant mice I. Studies on the characterization of enzyme defect and suitability as animal model of human disease. Pediatr. Res. 13:807-811.

28. Walser, M. 1983. Urea cycle disorders and other hereditary hyperammonemic syndromes. In The Metabolic Basis of Inherited Disease 5th ed. J. B. Wyngaarden, D. S. Ferdrickson, J. R. Goldstein, and M. S. Brown, editors. McGraw Hill Inc., New York. pp. 402-438.
29. Top, F. H., Jr. 1975. Control of adenovirus acute respiratory disease in U.S. Army trainees. Yale J. Biol. Med. 48:185-195.

30. Chaloner-Larsson, G., G. Contreras, J. Furesz, D. W. Boucher, D. Krepps, G. R. Humphreys, and S. M. Mohanna. 1986. Immunization of canadian Armed Forces personnel with live types 4 and 7 adenovirus vaccines. Can. J. Public Health. 77:367-370.

31. Tremblay, M. L., S. P. Yee, R. H. Persson, S. Bacchetti, J. R. Smiley, and P. E. Branton. 1985. Activation and inhibition of expression of the 72,000-Da early protein of herpes simplex virus type 1. Virology. 144:35-45.

32. Wong, K. M., and A. J. Levine. 1986. Identification and mapping of Epstein-Barr virus early antigens and demonstration of a viral gene activator that function in trans. J. Virol. 60:149-156.

33. Tevethia, M. J., D. J. Spector, K. M. Leisure, and M. F. Stinski. 1987 Participation of two human cytomegalovirus immediate early gene regions in transcriptional activation of adenovirus promoters. Virology. 161:276-285.

34. Straus, S. E. 1984. Adenovirus infections in human. In The Adenoviruses. H. S. Ginsberg, editor. Plenum Publishing Corp., New York. 451-496.

35. Griffiths, P. D., D. S. Ellis, and A. J. Zuckerman. 1990. Other common types of viral hepatitis and exotic infections. Br. Med. Bull. 46:512-532. 